\title{
CHARACTERIZATION OF CRUDE 5'-PHOSPHODIESTERASE FROM GERMINATED ADZUKI (VIGNA ANGULARIS L.) BEANS
}

\author{
Liew Phing Pui ${ }^{\boxplus}$, Abdulkarim Sabo Mohammed ${ }^{2}$, Hasanah Mohd Ghazali ${ }^{3}$ \\ ${ }^{1}$ Department of Food Science with Nutrition, UCSI University \\ Jalan Menara Gading 1, UCSI Heights, 56000 Cheras, Kuala Lumpur, Malaysia \\ ${ }^{2}$ Department of Microbiology and Biotechnology, Federal University Dutse \\ Dutse, Nigeria \\ ${ }^{3}$ Department of Food Science, Universiti Putra Malaysia \\ 43400 Selangor, Malaysia
}

\begin{abstract}
Background. 5'-Phosphodiesterase (5'-PDE) is an enzyme that hydrolyzes RNA to form 5'-inosine monophosphate (5'-IMP) and 5'-guanosine monophosphate (5'-GMP). These 5'-nucleotides can function as flavor enhancers. Adzuki beans (Vigna angularis L.) are found to be high in 5'-PDE.

Materials and methods. 5'-phosphodiesterase (5'-PDE) enzyme was characterized from adzuki beans, in which the optimum $\mathrm{pH}$ and temperature were determined. In addition, the stability of 5'-PDE was assessed at different $\mathrm{pH}$ and temperature. The effects of cations and EDTA were evaluated to characterize the 5'-PDE enzymes further.

Results. The alkaline 5'-phosphodiesterase has an optimum $\mathrm{pH}$ of 8.5. This enzyme is also thermostable, with an optimum temperature of $80^{\circ} \mathrm{C}$. The stability in terms of temperature and $\mathrm{pH}$ was also determined, and was found to be stable in the $\mathrm{pH}$ range of 7.0-8.5. This enzyme was found to retain more than $80 \%$ of its activity for 4 days at 60 and $65^{\circ} \mathrm{C}$. In addition, the effects of 14 different metal ions, 4 types of detergents and ethylenediaminetetraacetic acid (EDTA) on 5'-PDE were studied. $\mathrm{Ca}^{2+}, \mathrm{K}^{+}, \mathrm{Mg}^{2+}$ and $\mathrm{Li}^{+}$activated 5'-PDE while $\mathrm{Na}^{+}, \mathrm{Zn}^{2+}, \mathrm{Ni}^{+}, \mathrm{Hg}^{+}, \mathrm{Cu}^{2+}, \mathrm{Pb}^{2+}, \mathrm{Fe}^{2+}, \mathrm{Al}^{3+}, \mathrm{Ba}^{2+}$ and $\mathrm{Co}^{2+}$ were inhibitory. EDTA, Triton X-100 and sodium dodecyl sulfate (SDS) were strong inhibitors of 5'-PDE, while Tween 80 and Tween 20 were slightly inhibitory. The effects of cations and EDTA suggest that 5'-PDE from adzuki beans is a metalloenzyme.

Conclusion. Although 5'-PDE from adzuki beans has a high temperature optimum of $80^{\circ} \mathrm{C}$, the enzyme is more stable at $60^{\circ} \mathrm{C}$, and different cations affected the activity of the enzyme differently.
\end{abstract}

Keywords: 5'-phosphodiesterase, thermostability, optimum pH, detergents, cations

\section{INTRODUCTION}

5'-Phosphodiesterase (5'-PDE, EC 3.1.4.1) is the enzyme that digests phosphodiester bonds to produce a 5'-hydroxyl group, in which it hydrolyzes RNA to 5'-nucleotides. 5'-PDE is a useful tool in the area of biotechnology, especially in nucleic acid research labeling, characterization of oligonucleotides and also as an aid in sequence analysis (Harvey et al., 1970; Rosemeyer et al., 2002). As well as this, it is utilized in the study of genes related to obesity and insulin resistance and hepatitis C viruma (Santoro et al., 2009; Takahama et al., 2008). 5'-PDE can also be used for the production of mononucleotides, whereby the 
mononucleotides (5'-IMP and 5'-GMP) can function as flavor enhancers in the food industry (Beluhan et al., 2003; Rotola-Pukkila et al., 2019).

Previous studies have been done on germinating beans as sources of 5' -PDE such as barley, mung bean (Khutle et al., 2011), yellow soybean and black soybean (Utami et al., 2011). Also, 5'-PDE with different $\mathrm{pH}$ and temperature optima, as well as other characteristics, were reported for microorganisms such as Xanthomonas axonopodis (Lassila and Herschlag, 2008), Rhizobium legumniosarum (Jones et al., 2008), Aspergillus niger (Chohnan et al., 1994), Aspergillus fumigatus (Luo et al., 2017) and Escherichia coli (Miller et al., 2007); animals such as the cow (Rosemeyer et al., 2002) and plants as well, such as thale cress (Speath et al., 2007) and rose periwinkle flower (Aoyagi et al., 2006). There are even phosphodiesterases being produced artificially (Takebayashi et al., 2004) and obtained from human cells (Maldonado et al., 2008). Among the results (Singh et al., 2006) on 5'-PDE properties, it is interesting to note that 5'-PDE from some sources showed high $\mathrm{pH}$ optimum $(\mathrm{pH} 10)$. There is also (Lerch and Wolf, 1972) a 5'-PDE (from sugar beet leaves) which showed high-temperature stability $\left(80^{\circ} \mathrm{C}\right)$. Germinated adzuki beans (Pui et al., 2012) were found to have the highest amount of 5'-PDE when compared with mung bean, soybean, chickpea, black eye pea and petai (Parkia speciosa). Although 5 '-PDE has been characterized from different sources, there has been no work on the characterization of 5'-PDE from adzuki beans (Vigna angularis L.). Moreover, the effects of metal cations and detergents on the activity of 5'-PDE have been studied by only a few researchers (Henz et al., 2007; Ying et al., 2006). Characterization studies are also important to determine the stability of an enzyme under various conditions and to find ways to minimize denaturation, so that the enzyme may become useful in industry.

This study was conducted to determine the properties of 5'-phosphodiesterase isolated from adzuki ( $\mathrm{Vi}$ gna angularis $\mathrm{L}$.) beans that had been germinated for 15 hours. The scope of characterization of 5'-PDE included $\mathrm{pH}$ optimum, $\mathrm{pH}$ stability, temperature optimum and temperature stability, the stability of 5'-PDE at different storage temperatures and the effects of $\mathrm{pH}$ solutions on the storage. This work also describes the effects of metal ions and detergents on the activity of the enzyme.

\section{MATERIALS AND METHODS}

\section{Materials}

Adzuki (Vigna angularis L.) beans imported from Tian Jing, China, were bought at a local dry market in Sri Serdang, Selangor, Malaysia. The substrate for the enzyme assay, sodium thymidine 5'-monophosphate p-nitrophenyl ester (nitrophenyl-pT), was purchased from Sigma-Aldrich Chemie GmbH, Steinheim, Germany. All other chemicals in this research were of analytical grade.

\section{Extraction of enzymes from germinated adzuki beans}

Adzuki beans $(100 \mathrm{~g})$ were germinated by first soaking them in $200 \mathrm{~mL}$ of $0.3 \%$ (w/v) sodium hypochlorite solution for 5 minutes, after which the beans were rinsed 5 times with distilled water before being placed inside four sterilized beakers which were pre-autoclaved with $15 \mathrm{~mL}$ distilled water and cotton wool. Each beaker contained $25 \mathrm{~g}$ of seeds. The beakers were covered with aluminum foil, and the beans were allowed to germinate in the dark at room temperature $\left(28 \pm 2^{\circ} \mathrm{C}\right)$ for $15 \mathrm{~h}$. The germinated beans were then pooled and homogenized by grinding them with $400 \mathrm{~mL} 50 \mathrm{mM}$ acetate buffer (pH 4.5). The homogenate was stirred for 30 minutes before filtering through a piece of muslin cloth. The filtrate was subjected to centrifugation at $10^{\circ} \mathrm{C}$ for $15 \mathrm{~min}$ at 12,5000 $\times \mathrm{g}$ (Sartorius Model 3-18 k centrifuge, Sartorius AG, Weender Land Strasse, Gottingen, Germany; Dhule et al., 2006).

The resulting enzyme extract obtained above was then subjected to dialysis. Dialysis tubes $(15 \mathrm{~cm})$ were boiled in distilled water for half an hour and soaked in $500 \mathrm{~mL} \cdot 1 \mathrm{mM}$ ethylene diamine tetraacetic acid (EDTA) solution for 12 hours before use (Idris, 2000). The enzyme extract $(10 \mathrm{~mL})$ was added to individual dialysis tubes, tied and then placed in $1 \mathrm{~L} \cdot 50 \mathrm{mM}$ acetate buffer, $\mathrm{pH} 4.5$ and stirred for 12 hours at $4^{\circ} \mathrm{C}$. The buffer solution was replaced every 4 hours. The dialyzed extract was then used to determine the properties of the enzyme.

\section{5'-PDE activity assays}

The method of Harvey et al. (1970) was applied with modifications to determine the 5'-PDE activity. The 
reaction mixture (consisting of $0.1 \mathrm{~mL}$ enzyme extract, $0.2 \mathrm{~mL}$ of $200 \mathrm{mM}$ phosphate buffer, $\mathrm{pH} 7.0$, and $0.2 \mathrm{~mL} \cdot 1 \mathrm{mg} / \mathrm{mL}$ nitrophenyl-pT as a substrate) was incubated in a water bath $\left(10 \mathrm{~min}, 55^{\circ} \mathrm{C}\right)$, with deactivated enzyme in the same formulation as the control. The reaction was stopped with the addition of $0.5 \mathrm{~mL} \cdot 0.1 \mathrm{~N} \mathrm{NaOH}$ solution, followed by centrifugation $\left(12,5000 \times \mathrm{g}, 10^{\circ} \mathrm{C}\right.$, Sartorius AG, Weender Land Strasse, Germany). After centrifugation, the mixture was measured with a spectrophotometer $(405 \mathrm{~nm})$.

Specific activity was expressed as unit activity per mg protein, in which the unit $(U)$ of the enzyme was the amount of enzyme required to form $1 \mu \mathrm{mol}$ of $\mathrm{p}$ -nitrophenol per $\mathrm{mL}$ enzyme extract in $1 \mathrm{~min}$, at $55^{\circ} \mathrm{C}$ and $\mathrm{pH}$ 7.0. The protein content was determined according to Pui et al. (2012).

\section{Determination of $\mathrm{pH}$ optimum and $\mathrm{pH}$ stability}

The effect of $\mathrm{pH}$ on 5'-PDE was determined by assaying the activity of the enzyme at different $\mathrm{pH}$ using buffers (citrate, phosphate, Tris- $\mathrm{HCl}$, and carbonatebicarbonate) to obtain a buffering capacity between $\mathrm{pH} 3-10$. The concentration of each buffer was $200 \mathrm{mM}$.

A pH stability study was carried out by pre-incubating the enzyme extract $(0.1 \mathrm{~mL})$ in $0.2 \mathrm{~mL}$ buffer (at different $\mathrm{pH}$ ranging from $\mathrm{pH} 6$ to 10 ) in a capped Eppendorf tube for $1 \mathrm{~h}$ at $80^{\circ} \mathrm{C}$ in a water bath (Ying et al., 2006). After that, $0.2 \mathrm{~mL}$ of $1.0 \mathrm{mg} / \mathrm{mL}$ nitrophenyl-pT was added to the test tube, mixed, and incubated at $80^{\circ} \mathrm{C}$ in a water bath for 10 minutes to allow conversion of the substrate into p-nitrophenol (yellow) and 5'-nucleotides as products. Then, $0.5 \mathrm{~mL}$ of $0.1 \mathrm{~N}$ $\mathrm{NaOH}$ solution was added to terminate the reaction. The absorbance was measured at $405 \mathrm{~nm}$.

\section{Determination of temperature optimum and thermostability}

Determination of the optimum temperature of 5'-PDE was conducted by measuring the enzyme activity at different temperatures ranging from $20-95^{\circ} \mathrm{C}$. Temperature stability was determined by pre-incubating $0.1 \mathrm{~mL}$ enzyme plus $0.2 \mathrm{~mL} \cdot 200 \mathrm{mM}$ of Tris- $\mathrm{HCl}$ buffer $\mathrm{pH} 8.5$ at different temperatures $(20,30,40$, $50,60,70,80$ and $90^{\circ} \mathrm{C}$ ), for 1 hour before assaying the $5^{\prime}$-PDE described earlier at $80^{\circ} \mathrm{C}$ (Ying et al., 2006).

\section{Determination of stability of 5'-PDE at the optimum temperature and $\mathrm{pH}$, and other temperatures and $\mathrm{pH}$}

The $\mathrm{pH}$-temperature stability of the enzyme was studied by incubating the enzyme at 60,65 and $70^{\circ} \mathrm{C}$ at $\mathrm{pH}$ 7.5 (200 mM phosphate buffer) and pH $8.5(200 \mathrm{mM}$ Tris-HCl buffer) for 1 hour before measuring the residual activity (Ying et al., 2006). The enzyme activity was determined at different time intervals.

\section{Effects of detergents and EDTA on 5'-phosphodiesterase activity}

The effects of detergents (Triton X-100, Tween-20, Tween-80 and Sodium Dodecyl Sulfate, SDS) and ethylenediaminetetraacetic acid (EDTA) on the enzyme activity were determined by pre-incubating the enzyme extract $(0.1 \mathrm{~mL})$ with $0.1 \mathrm{~mL}$ of detergent or EDTA (all at a final concentration of $10 \mathrm{mM}$ ), in $0.1 \mathrm{~mL} 200 \mathrm{mM}$ Tris- $\mathrm{HCl}$ buffer, for $1 \mathrm{~h}$ at $80^{\circ} \mathrm{C}$ (Ying et al., 2006). $0.2 \mathrm{~mL} 1.0 \mathrm{mg} / \mathrm{mL}$ nitrophenyl-pT (substrate) was then added to the enzyme-detergent mixture and enzyme-EDTA mixture and further incubated for $10 \mathrm{~min}$ at $80^{\circ} \mathrm{C}$. $\mathrm{NaOH}$ solution $(0.5 \mathrm{~mL}, 0.1 \mathrm{~N})$ was added to stop the reaction. The control reaction mixture which did not contain detergent/EDTA was considered as having $100 \%$ activity, and the activity of the enzyme exposed to detergents and EDTA was expressed as a relative activity to that of the control.

\section{Effects of metal cations on 5'-phosphodiesterase activity}

The effect of metal ions on the activity of 5'-PDE was determined using various metal ions $\left(\mathrm{Li}^{+}, \mathrm{Na}^{+}, \mathrm{K}^{+}, \mathrm{Mg}^{2+}\right.$, $\left.\mathrm{Ca}^{2+}, \mathrm{Ba}^{2+}, \mathrm{Fe}^{3+}, \mathrm{Co}^{2+}, \mathrm{Ni}^{2+}, \mathrm{Cu}^{2+}, \mathrm{Zn}^{2+}, \mathrm{Hg}^{2+}, \mathrm{Al}^{3+}, \mathrm{Pb}^{2+}\right)$ all at a final concentration of $10 \mathrm{mM}$. Enzyme-metal ion mixtures $(0.1 \mathrm{~mL}$ enzyme, $0.1 \mathrm{~mL}$ cation solution and $0.1 \mathrm{~mL} \cdot 200 \mathrm{mM}$ Tris-HCl buffer) were pre-incubated at $80^{\circ} \mathrm{C}$ for 1 hour before adding $0.2 \mathrm{~mL} \cdot 1 \mathrm{mg} / \mathrm{mL}$ nitrophenyl-pT for further incubation at $80^{\circ} \mathrm{C}$ for $10 \mathrm{~min}$. The reaction was terminated by adding $0.5 \mathrm{~mL} \cdot 0.1 \mathrm{~N}$ $\mathrm{NaOH}$. The activity of the enzyme without added cation served as the control, where $0.1 \mathrm{~mL}$ enzyme and $0.2 \mathrm{~mL} \cdot 200 \mathrm{mM}$ Tris- $\mathrm{HCl}$ buffer were pre-incubated at $80^{\circ} \mathrm{C}$ for 1 hour before adding $0.2 \mathrm{~mL}$ of $1.0 \mathrm{mg} / \mathrm{mL} \mathrm{ni}-$ trophenyl-pT for further incubation at $80^{\circ} \mathrm{C}$ for $10 \mathrm{~min}$. Enzyme activity is expressed as relative activity based on the activity of the control. 
The effect of different concentrations of selected metal ions $\left(\mathrm{Ca}^{2+}, \mathrm{K}^{+}, \mathrm{Mg}^{2+}, \mathrm{Li}^{2+}, \mathrm{Na}^{+}, \mathrm{Al}^{3+}\right)$ on the activity of $5^{\prime}$-PDE was determined by pre-incubating $0.1 \mathrm{~mL}$ enzyme and $0.1 \mathrm{~mL}$ cation solution at $80^{\circ} \mathrm{C}$ for 1 hour before adding $0.2 \mathrm{~mL} \cdot 1.0 \mathrm{mg} / \mathrm{mL}$ nitrophenyl-pT for further incubation at $80^{\circ} \mathrm{C}$ for $10 \mathrm{~min}$. The concentrations of metal cations were $0,2,4,6$, 8 and $10 \mathrm{mM}$. The reaction was stopped by adding $0.5 \mathrm{~mL} \cdot 0.1 \mathrm{~N} \mathrm{NaOH}$. The activity of enzyme without any addition of cation functioned and treated as above served as the control. Enzyme activity is expressed as relative activity based on the activity of the control.

\section{RESULTS AND DISCUSSIONS}

\section{Enzyme extraction and dialysis}

The results of the extraction are shown in Figure 1 where dialysis was found to increase 5'-PDE specific enzyme activity from $0.34 \mu \mathrm{mol} \mathrm{p}$-nitrophenol $/ \mathrm{min} /$ $\mathrm{mg}$ protein (from extraction) to $0.43 \mu \mathrm{mol}$ p-nitrophe$\mathrm{nol} / \mathrm{min} / \mathrm{mg}$ protein. The increase was due to the reduction in protein content during dialysis.

\section{pH optimum and pH stability}

The obtained results show that the optimum $\mathrm{pH}$ of 5'-PDE was pH 8.5 (Fig. 2), where 5'-PDE activity

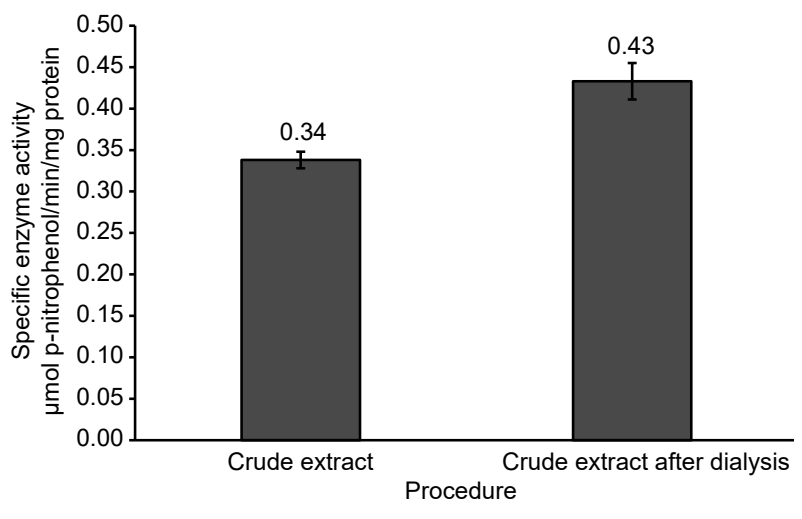

Fig. 1. Specific activity of 5'-PDE after extraction and dialysis. The error bars represent the mean \pm standard deviation of three replicates

increased with an increasing $\mathrm{pH}$ until $\mathrm{pH}$ 8.5. The activity of the enzyme was minimal at acidic $\mathrm{pH}$ and increased from $\mathrm{pH} 6.0$ until $\mathrm{pH}$ 8.5. After that, the activity dropped significantly as the $\mathrm{pH}$ was further increased. This suggests that the enzyme requires a relatively alkaline $\mathrm{pH}$ to function effectively. Changes in the $\mathrm{pH}$ of the medium resulted in changes in the ionic statues at the active sites and changes in the activity of the enzymes and, hence, the reaction rate. Changes in

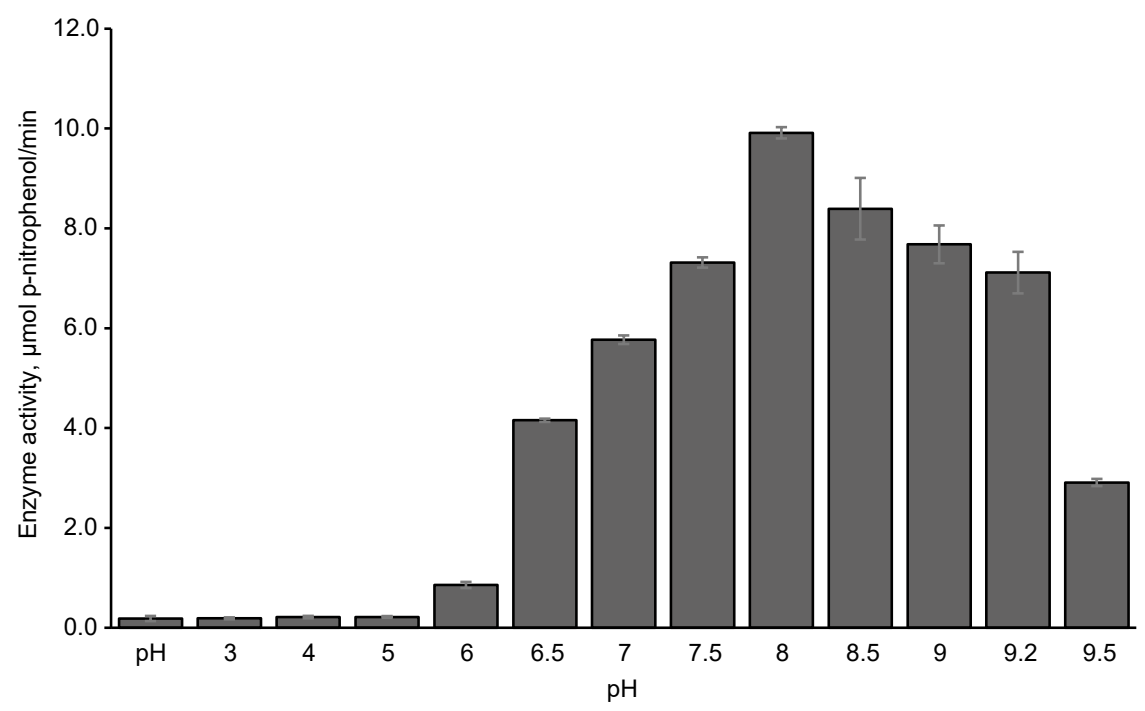

Fig. 2. 5'-PDE activity at different $\mathrm{pH}$. The error bars represent the mean \pm standard deviation of three replicates 
$\mathrm{pH}$ may also alter the three-dimensional shape of the enzyme (Pelczar et al., 2004).

There are several 5'-PDEs that are active in alkaline pH. 5'-PDE from the barley malt rootlet has shown a pH optimum of 8.9 (Beluhan et al., 2003). Higher $\mathrm{pH}$ optima have also been reported. Sugar beet leaf 5'-PDE has an optimum $\mathrm{pH}$ of 9.2, and the enzyme activity was measured using nitrophenyl p-uridine as the substrate (Lerch and Wolf, 1972). Bowles (1991) found that 5'-PDE from malted barley rootles have a $\mathrm{pH}$ optimum ranging from $\mathrm{pH}$ 8.5-9.5.

On the other hand, the $\mathrm{pH}$ optimum of 5'-PDE from other sources can also vary substantially. Ying et al. (2006) reported that 5'-PDE from Penicillium citrinum has a $\mathrm{pH}$ optimum of $\mathrm{pH} 5.4$, where the enzyme was shown to have no activity at $\mathrm{pH}>8.0$. 5'-PDE malt rootlets showed that its $\mathrm{pH}$ optimum was between $\mathrm{pH}$ 5.5-6.0 (Zou et al., 2008), while 5'-PDE from Aspergillus fumigatus has a $\mathrm{pH}$ optimum of 5.0 (Luo et al., 2017). From this study, it can be concluded that the $\mathrm{pH}$ optimum of 5'-PDE from adzuki bean is in the alkaline region, and the $\mathrm{pH}$ optimum is organism-specific.

Table 1 shows that 5 '-PDE is stable between $\mathrm{pH} 7.0$ and $\mathrm{pH} 8.5$, where the relative enzyme activity ranges from $100-132.6 \%$. The activity dropped dramatically as the $\mathrm{pH}$ was increased or decreased beyond this range. It was also demonstrated that it was most active and stable at $\mathrm{pH} 7.5$ but unstable over $\mathrm{pH} 9.0$, as well

Table 1. The relative stability of 5'-phosphodiesterase at different $\mathrm{pH}$

\begin{tabular}{cc}
\hline $\mathrm{pH}$ & Relative enzyme activity, $\%$ \\
\hline 6.0 & $6.1 \pm 1.1$ \\
6.5 & $95.5 \pm 4.9$ \\
7.0 & $132.6 \pm 5.2$ \\
7.5 & $384.3 \pm 5.3$ \\
8.0 & $305.5 \pm 10.4$ \\
8.5 & $100 \pm 5.3$ \\
9.0 & $8.9 \pm 4.0$ \\
9.5 & $7.8 \pm 1.7$ \\
\hline
\end{tabular}

5'-PDE at $\mathrm{pH} 8.5$ (optimum $\mathrm{pH})$ was taken as control $(100 \%$ relative enzyme activity). as at $\mathrm{pH} 6.0$ and below. The enzyme catalysis activity was at $\mathrm{pH} 8.5$ for 10 minutes, but the enzyme was stable in the range $\mathrm{pH} 7.0-8.0$.

At $\mathrm{pH} 8.5$, the alkaline condition causes slight alteration in 5'-PDE enzyme conformation, which leads to the exposure of more active sites of the enzyme. However, the prolonged exposure of high $\mathrm{pH}$ may lead to the changing of conformation or denaturation of the enzyme. There are some 5'-PDE with similar $\mathrm{pH}$ stability properties as the enzyme from adzuki beans. Harvey et al. (1967) also found that 5'-PDE from carrots was stable between $\mathrm{pH} 8.5$ to $\mathrm{pH}$ 9.0. Overall, the enzyme was stable in slightly alkaline solutions.

\section{Temperature optimum and stability}

The activity-temperature curve for 5'-PDE is shown in Figure 3, with the optimum temperature for 5'-PDE fixed at $80^{\circ} \mathrm{C}$, and nitrophenyl-pT as the substrate. The activity increased when the temperature was increased from 20 to $80^{\circ} \mathrm{C}$. At $95^{\circ} \mathrm{C}$, the remaining enzyme activity was only $12 \%$ of the activity at the optimum temperature. No enzyme activity was detected at $100^{\circ} \mathrm{C}$.

The choice of temperature is critical for the determination of enzyme activity and purification of enzymes. This information will be extremely useful, especially to give a clear picture of the working temperature of the enzyme to avoid denaturation.

According to Sowdhamini and Balaram (1993), an increase in temperature generally increases enzyme activity. As the temperature increases, molecular motion increases resulting in more molecular collisions.

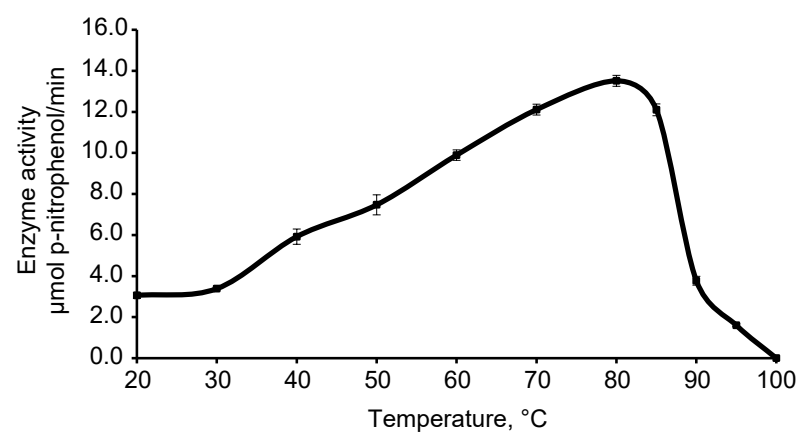

Fig. 3. 5'-PDE activity at the different reaction temperatures. The error bars represent the mean \pm standard deviation of three replicates 
If, however, the temperature rises above a certain point, that heat will denature the enzyme, causing loss of its three-dimensional functional shape by denaturing its hydrogen bonds. Thus, the protein will denature as the temperature increases beyond the optimum temperature. A slow reaction rate was observed at a low temperature for 5'-PDE activity. The cold temperature slows down enzyme activity by decreasing molecular motion (Sowdhamini and Balaram, 1993). The information obtained from this experiment has also provided a better understanding of the working environment of this crude 5'-PDE preparation that would help to avoid denaturation of the enzyme during purification or application.

The data obtained in this study coincide with the findings of research by Lerch and Wolf (1972), where high-temperature stability $\left(80^{\circ} \mathrm{C}\right)$ was displayed by 5 '-PDE purified from sugar beet leaves (Lerch and Wolf, 1972). However, in general, the temperature optimum for $5^{\prime}$-PDE was found to be $70^{\circ} \mathrm{C}$ and below. This can be seen in 5'-PDE from germinated barley (Dhule et al., 2006), Penicillium citrinum (Ying et al., 2006), Aspergillus fumigatus (Luo et al., 2017) and malt rootlet (Zou et al., 2008) which had temperature optimums of $60^{\circ} \mathrm{C}, 65^{\circ} \mathrm{C}, 60^{\circ} \mathrm{C}$ and $70^{\circ} \mathrm{C}$, respectively.

When compared to $5^{\prime}$-PDE from other sources, the enzyme from adzuki beans has excellent thermostability properties. This is considered an important and useful criterion for industrial applications. The enzyme was stable up to $60^{\circ} \mathrm{C}$ (Fig. 4) even after exposure for 1 hour at that temperature. After $60^{\circ} \mathrm{C}$, the enzyme activity started to decrease drastically, where a complete loss of activity was observed at $90^{\circ} \mathrm{C}$. Thus, applications of the enzyme in an industrial setting should be made at temperatures below $60^{\circ} \mathrm{C}$. Hua and Huang (2010), in their recent study, found 5 '-PDE from barley rootlets to be stable at $70^{\circ} \mathrm{C}$ for 420 minutes. On the other hand, Beluhan and Maric (2011), in their work on 5'-PDE from barley rootles, observed retention of $70 \%$ relative activity after 120 min of incubation at $70^{\circ} \mathrm{C}$. Besides that, 5'-PDE from yeast extract, which has an optimum temperature of $65^{\circ} \mathrm{C}$, showed decreasing stability with an increase in temperature (Sombutyanuchi et al., 2001). The yeast $5^{\prime}$-PDE was stable at $60^{\circ} \mathrm{C}$ for 200 minutes. However, at 65,70 and $75^{\circ} \mathrm{C}$, the enzyme was stable for 120 , 60 and 40 minutes, respectively, showing a decreasing trend in thermostability. At $80^{\circ} \mathrm{C}$, the enzyme was only stable for 20 minutes.

\section{Stability of 5'-PDE at optimum temperature and $\mathrm{pH}$, and other temperatures and $\mathrm{pH}$}

5 '-PDE had a reduction of $48.5 \%$ enzyme activity after $30 \mathrm{~min}$ pre-incubation. The activity further reduced with $93 \%$ loss of activity when pre-incubated at 120 $\mathrm{min}$. This is in agreement with the work of Lerch and Wolf (1972), where 5'-PDE from sugar beet leaves experienced $50 \%$ activity lost after 10 minutes $\left(\right.$ at $80^{\circ} \mathrm{C}$ ), although its optimum temperature was $80^{\circ} \mathrm{C}$.

Figure 6 shows that on the first day of incubation, 5'-PDE was stable (relative enzyme activity more than $80 \%$ ) under all conditions tested. At 60 and $65^{\circ} \mathrm{C}$,

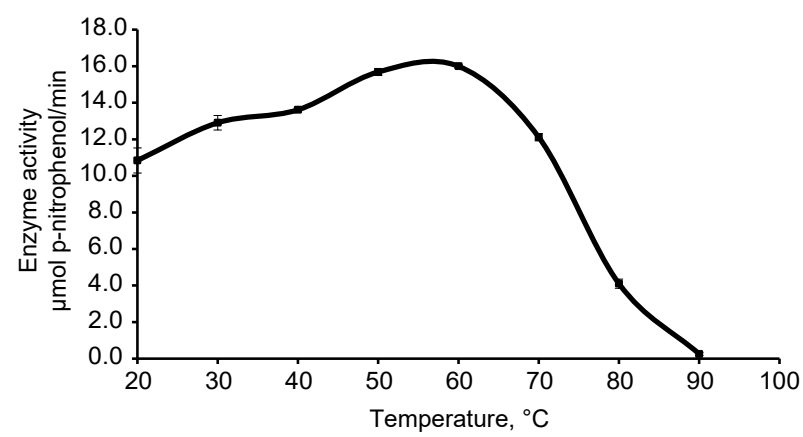

Fig. 4. Stability of 5'-PDE pre-incubated at different temperatures for 1 hour. The $\mathrm{pH}$ was maintained at $\mathrm{pH}$ 8.5. The error bars represent the mean \pm standard deviation of three replicates

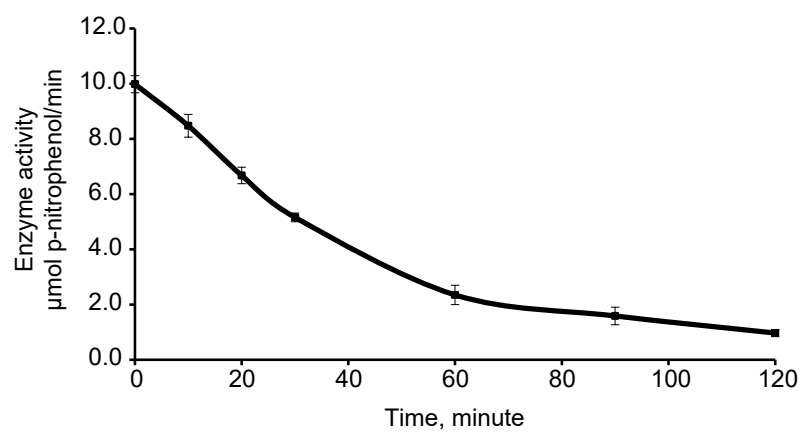

Fig. 5. Stability of 5'-PDE at optimum $\mathrm{pH}(\mathrm{pH} 8.5)$ and optimum temperature $\left(80^{\circ} \mathrm{C}\right)$ with time. The error bars represent the mean \pm standard deviation of three replicates 


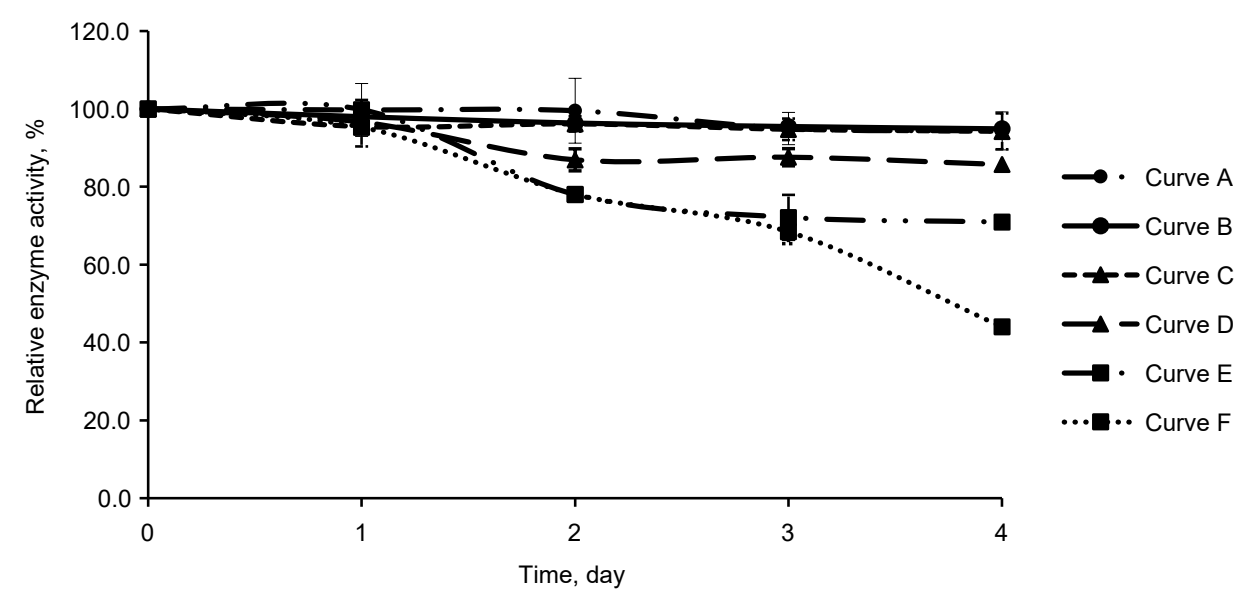

Fig. 6. Stability of $5^{\prime}-\mathrm{PDE}$ at $\mathrm{pH} 7.5$ and $\mathrm{pH} 8.5$ and $60^{\circ} \mathrm{C}, 65^{\circ} \mathrm{C}$ and $70^{\circ} \mathrm{C}$ : condition $\mathrm{A}-\mathrm{pH}$ 7.5 and $60^{\circ} \mathrm{C}$, condition $\mathrm{B}-\mathrm{pH} 8.5$ and $60^{\circ} \mathrm{C}$, condition $\mathrm{C}-\mathrm{pH} 7.5$ and $65^{\circ} \mathrm{C}$, condition $\mathrm{D}-$ $\mathrm{pH} 8.5$ and $65^{\circ} \mathrm{C}$, condition $\mathrm{E}-\mathrm{pH} 7.5$, and $70^{\circ} \mathrm{C}$, condition $\mathrm{F}-\mathrm{pH} 8.5$ and $70^{\circ} \mathrm{C}$. The error bars represent the mean \pm standard deviation of three replicates

regardless of the $\mathrm{pH}$ of the reaction (conditions $\mathrm{A}$, B, C and D), 5'-PDE retained more than $80 \%$ of its relative enzyme activity on the $4^{\text {th }}$-day of incubation. However, at $70^{\circ} \mathrm{C}$, the relative activity of $5^{\prime}$-PDE incubated in $\mathrm{pH} 7.5$, and $\mathrm{pH} 8.5$ dropped to $71 \%$ (condition E) and 44\% (condition F), respectively. Moreover, it was observed that 5 '-PDE lost more activity at $\mathrm{pH}$ 8.5 compared to $\mathrm{pH} 7.5$, especially on day 4 of incubation, where the activity at $\mathrm{pH} 7.5$ was 1.61 times greater than the activity at $\mathrm{pH} 8.5$. 5'-PDE from barley was found to be stable at $70^{\circ} \mathrm{C}$ for 2 hours (Beluhan and Maric, 2003). However, there was no report on the stability of $5^{\prime}$-PDE at $70^{\circ} \mathrm{C}$ for beyond a few hours.

\section{Effects of detergents and EDTA on 5'-phosphodiesterase activity}

Figure 7 shows that Tween 80 had a slight inhibitory effect on 5'-PDE activity as it decreased the activity by $23.1 \%$ relative to the activity of the control. A greater degree of inhibition was obtained in the presence of Tween 20, where the relative activity of the enzyme was $69.4 \%$. The loss in enzyme activity was $75.2 \%$ and $96.8 \%$, respectively, in the presence of Triton X-100 and SDS. From the experiment, it can be concluded that 5'-PDE from adzuki beans is inhibited by detergents.

However, each of the detergents has a different degree of inhibition towards the enzyme. Ying et al. (2006), who studied the effects of detergents on 5'-PDE from Penicillium citrinum, reported the presence of $0.1 \%(\mathrm{v} / \mathrm{v})$ and $0.2 \%(\mathrm{v} / \mathrm{v})$ as compared to $12 \%(\mathrm{v} / \mathrm{v})$ Tween $80(10 \mathrm{mM})$ used in this experiment. Tween 80 in the reaction medium did not have a profound or high inhibitory effect. When the researchers used Triton $\mathrm{X}-100$ at $0.2 \%(\mathrm{v} / \mathrm{v})$, a strong inhibitory effect was obtained where the relative activity was $23 \%$. On the other hand, $0.1 \%(\mathrm{w} / \mathrm{v})$ and $0.2 \%(\mathrm{w} / \mathrm{v})$ SDS reduced 5 '-PDE activity to $55 \%$ and $42 \%$, respectively.

Although the presence of a high concentration of detergents often resulted in protein denaturation, nonionic detergent concentrations below $0.1 \%(\mathrm{w} / \mathrm{v})$ are usually not harmful to proteins (Scopes, 1994). The detergents used in this experiment (Tween 80, Tween 20 and Triton X 100) are examples of non-ionic detergents. The most common chelating agent is ethylene diamine tetraacetic acid (EDTA). If the enzyme is stable or its activity increases after pre-incubation with EDTA, it means the enzyme is affected by metals. On the other hand, if the activity of the enzyme drops after the addition of EDTA, the enzyme contains metal as a cofactor that is removed by EDTA. Thus, how EDTA inhibits an enzyme would indicate whether it is a metalloenzyme or a metal-activated enzyme.

The results shown in Figure 7 clearly show that the presence of EDTA greatly affected the activity of the enzyme such that only $0.6 \%$ of the control activity remained. This indicates that 5 '-PDE from adzuki 


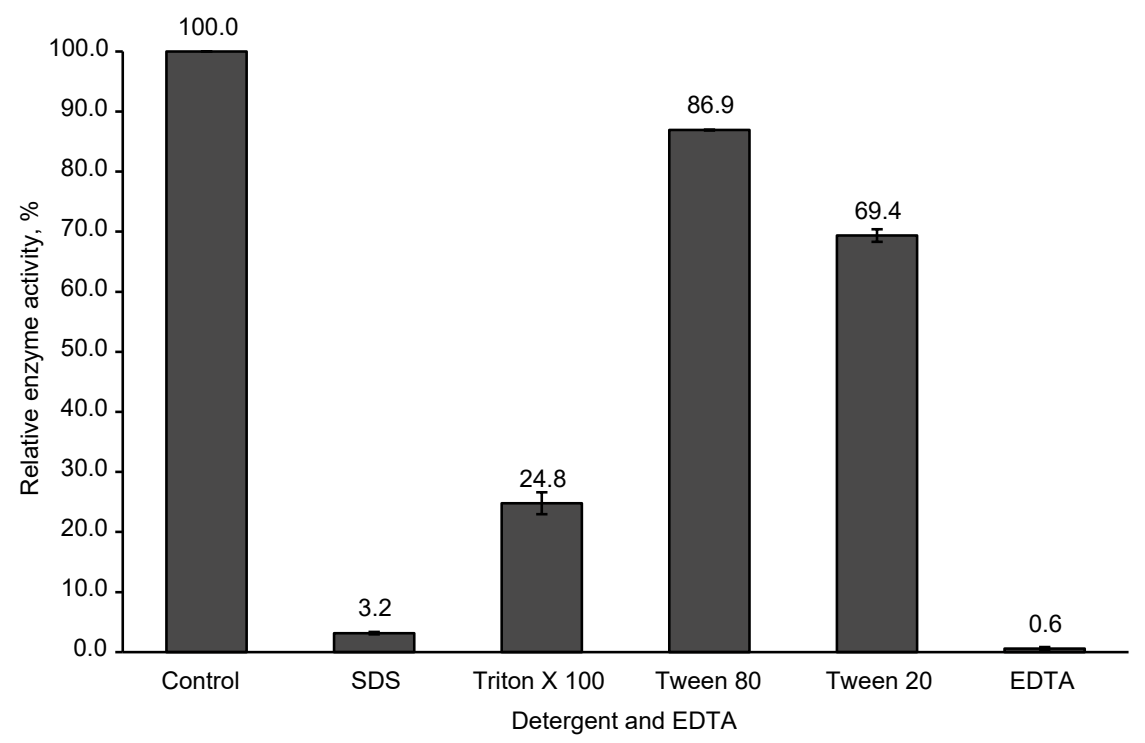

Fig. 7. Effects of detergents and EDTA on the activity of 5'-PDE. Error bars: standard deviations; results are mean of three determinations

beans is probably a metalloenzyme, meaning that the enzyme requires metal as a cofactor. EDTA has been reported as an inhibitor of 5'-PDE from different kinds of sources, such as beet (Lerch and Wolf, 1972) and rat submandibular salivary glands (Henz et al., 2007). A similar effect was also reported by Beluhan and Maric (2003) on 5'-PDE from barley, where $1 \mathrm{mM}$ EDTA and $10 \mathrm{mM}$ decreased relative enzyme activity to $77 \%$ and $10 \%$ of the control activity, respectively. This indicates that 5'-PDE from adzuki beans is probably a metalloenzyme, meaning that the enzyme requires metal as a cofactor.

\section{Effects of metal cations on 5'-phosphodiesterase activity}

Metal ions play important roles in the biological functions of many enzymes, mainly as cofactors. Various metal ions were investigated for their effects on 5'-PDE activity. The effects of different metal ions on 5'-PDE activity are shown in Figure 8. Out of 14 metal cations tested, only four were found to enhance the activity of the enzyme as they increased the activity to more than $100 \%$ of the control. The other metal ions caused either a slight or significant inhibition of the enzyme.
From Figure 8, most cations inhibited the enzyme significantly. However, the enzyme activity was strongly activated by $\mathrm{Ca}^{2+}, \mathrm{K}^{+}$and $\mathrm{Mg}^{2+}$ (at $10 \mathrm{mM}$ concentration) with the relative activity of $249 \%$, $214 \%$ and $179 \%$, respectively, compared to the activity of the control. However, the enzyme activity was increased only slightly ( $120 \%$ relative activity) by $\mathrm{Li}^{+}$. These results suggest that the 5'-PDE from adzuki beans is also a metalloenzyme. Figure 8 also shows that $\mathrm{Na}^{+}, \mathrm{Zn}^{2+}, \mathrm{Ni}^{2+}$ and $\mathrm{Hg}^{2+}$ (all $10 \mathrm{mM}$ final concentration) acted as an inhibitor of 5'-PDE activity where the activity of the enzyme decreased to $77.3 \%, 49.0 \%$, $44.4 \%$ and $39.8 \%$, respectively. The other metal cations were found to decrease the activity of the enzyme even more. The activity of the enzyme was almost completely removed by $\mathrm{Co}^{2+}$, to $8 \%$ of the relative activity compared to initial activity.

The present study also showed that there are metal cations that are capable of inhibiting 5'-PDE from adzuki beans. $\mathrm{Zn}^{2+}$ was also found to be inhibitory to 5'-PDE from adzuki beans (Fig. 8). According to Beluhan and Maric (2003), as the concentration of $\mathrm{Zn}^{2+}$ increased (from $1 \mathrm{mM}$ to $10 \mathrm{mM}$ ), the relative activity of 5'-PDE from barley malt sprouts decreased. It has been reported by Flaganan and Zbarsky (1976) that 


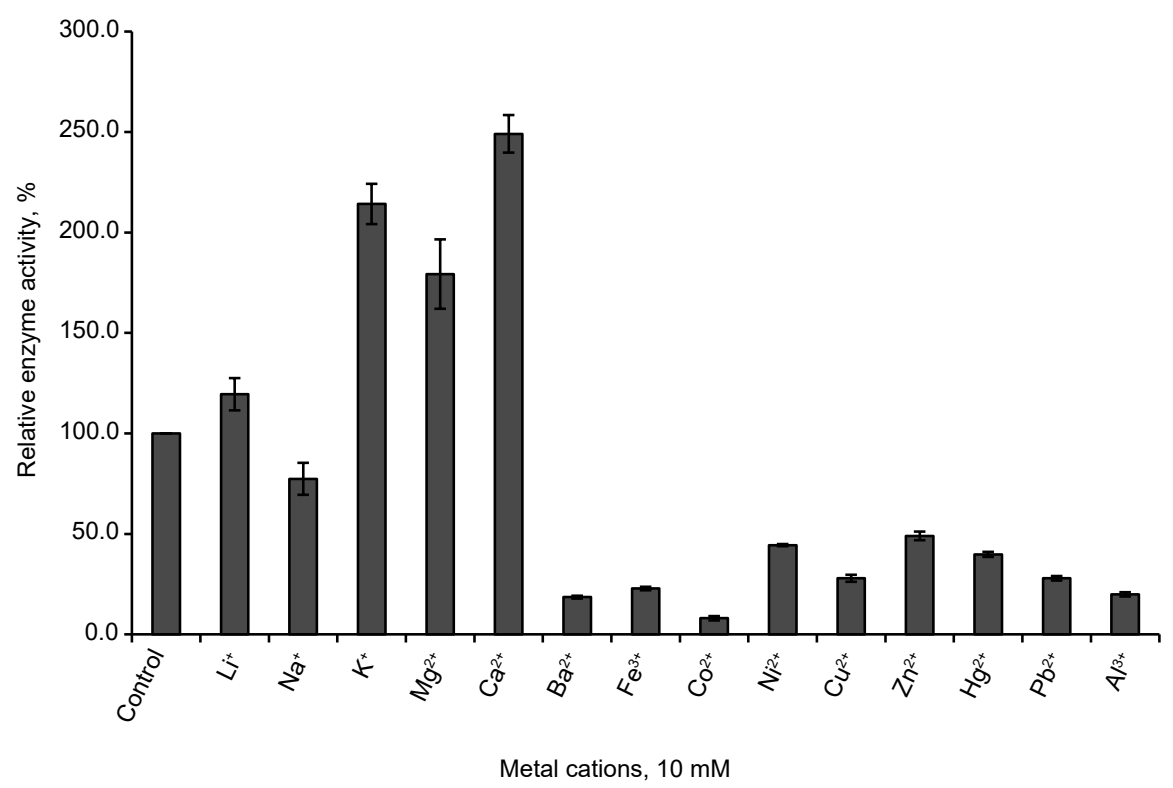

Fig. 8. Effects of metal ions on the activity of 5'-PDE. Error bars: standard deviations; results are mean of three determinations

$10 \mathrm{mM} \mathrm{Ni}^{2+}$ was only slightly inhibitory $(91 \%)$ to the enzyme from rat intestine.

Inhibition of 5'-PDE by $\mathrm{Hg}^{2+}, \mathrm{Cu}^{2+}, \mathrm{Pb}^{2+}, \mathrm{Al}^{3+}, \mathrm{Fe}^{2+}$ and $\mathrm{Fe}^{3+}$ has been reported by Chohnan et al. (1994), Lerch and Wolf (1972) and Futai and Mizuno (1967). Ying et al. (2006) reported on the strong inhibitory effect of $\mathrm{Cu}^{2+}$ on 5'-PDE from Penicillium citrinum where at $1 \mathrm{mM}$, and $2 \mathrm{mM}$, the activity of the enzyme declined to $1.6 \%$ and $4 \%$, respectively. Flaganan and Zbarsky (1976) also showed that as the concentration of $\mathrm{Cu}^{2+}$ in the reaction mixture increased from $1 \mathrm{mM}$ to $10 \mathrm{mM}$, the relative activity of 5'-PDE from rat intestine decreased from $74 \%$ to $34 \%$. On the other hand, Beluhan et al. (2003) reported a mild decrease in 5'-PDE activity from $93 \%$ to $69 \%$ when $1 \mathrm{mM}$ and $10 \mathrm{mM} \mathrm{Cu}^{2+}$ were present in the reaction mixture; while Luo et al. (2017) also reported that 5'-PDE from Aspergillus fumigatus were partially inhibited by $\mathrm{Cu}^{2+}$. There is a report on the role of $\mathrm{Pb}^{2+}$ as an inhibitor of 5'-PDE.

Chohnan et al. (1994) found that $\mathrm{Fe}^{2+}$ and $\mathrm{Fe}^{3+}$ inhibited 5'-PDE from Aspergillus niger, while Luo et al. (2017) reported on inhibition of the 5'-PDE from Aspergillus fumigatus by $\mathrm{Fe}^{3+}$. Inhibition of 5'-PDE from Aspergillus niger by $\mathrm{Co}^{2+}$ has been reported by Chohnan et al. (1994), although Lerch and Wolf (1972) reported that the cation activated the enzyme from sugar beet. According to Ying et al. (2006), $1 \mathrm{mM}$ of $\mathrm{Co}^{2+}$ had a slight inhibitory effect, where it reduced the activity of 5'-PDE from Penicillium citrinum to $75 \%$. This is in contrast with other reports which stated that $1 \mathrm{mM} \mathrm{Co}^{2+}$ increased the relative activity to $114 \%$ (Futai and Mizuno, 1967), and $2 \mathrm{mM}$ increased the relative activity to $116 \%$ (Harvey et al., 1967). There has been no report on the effects of $\mathrm{Ba}^{2+}$ on 5'-PDE from any sources.

The results of the effects for different concentrations of selected cations on 5'-PDE activity are shown in Table 2. $\mathrm{Li}^{+}$showed no significant effects on 5' -PDE at concentrations less than $4 \mathrm{mM}$. At $6 \mathrm{mM}$ concentration, $\mathrm{Li}^{+}$caused the activity of the enzyme to increase by 1.48 times that of the control. However, the relative activity of the enzyme decreased (but did not inhibit) as the concentration of $\mathrm{Li}^{+}$was further increased. So far, there has been no report on the effects of $\mathrm{Li}^{+}$on 5'-PDE activity.

When the effect of $\mathrm{Na}^{+}$was investigated further, it was found that different concentrations of $\mathrm{Na}^{+}$affected the enzymatic activity of 5'-PDE differently. Thus, the effect of $\mathrm{Na}^{+}$on 5 '-PDE is rather interesting, where 
at final concentrations of up to $8 \mathrm{mM}$, the cation was found to stimulate the activity of 5'-PDE. However, at $8 \mathrm{mM}$, the relative activity was lower than at $6 \mathrm{mM}$ (Table 2). An inhibitory effect was observed when the concentration of $\mathrm{Na}^{+}$was $10 \mathrm{mM}$. The results obtained are consistent with those from a few studies that reported $\mathrm{Na}^{+}$as a slight activator of the enzyme (Futai and Mizuno, 1967; Wang et al., 1993).

However, $\mathrm{K}^{+}$has a different effect on the catalytic reaction on the enzyme compared to $\mathrm{Ca}^{2+}$ (Table 2). It was observed that the relative activity of 5'-PDE exhibit a proportional increase with an increasing $\mathrm{K}^{+}$ concentration. At $10 \mathrm{mM} \mathrm{K}^{+}$concentration, 5'-PDE activity was 2.15 times greater than that of the control. Ying et al. (2006), who studied the effects of $\mathrm{K}^{+}$on 5'-PDE from Penicillium citritum found that the activity of the enzyme increased from $150 \%$ to $172 \%$ as the concentration of $\mathrm{K}^{+}$added increased from $1 \mathrm{mM}$ to $2 \mathrm{mM}$, respectively. They also reported on the activation of enzyme activity by $10 \mathrm{mM}$ of $\mathrm{Mg}^{2+}$. The activity of 5'-PDE increased as the concentration of $\mathrm{Mg}^{2+}$ increased from $1 \mathrm{mM}$ to $6 \mathrm{mM}$. The maximum stimulatory effect of $\mathrm{Mg}^{2+}$ on 5'-PDE was observed at $6 \mathrm{mM}$ with a $231 \%$ increase in activity. However, above this concentration, the strong stimulatory effect by $\mathrm{Mg}^{2+}$ was slightly reduced.

Activation of 5'-PDE from adzuki beans by $\mathrm{Mg}^{2+}$ is also consistent with research on the effects of $\mathrm{Mg}^{2+}$ on 5'-PDE from different sources, where studies revealed that $\mathrm{Mg}^{2+}$ activated the enzyme regardless of the type of sources of the enzyme itself. Harvey et al. (1967) found that $2 \mathrm{mM}$ of $\mathrm{Mg}^{2+}$ increased the relative activity to $223 \%$, whereas for 5 '-PDE from sugar beet (Lerch and Wolf, 1972), the relative activity increased to $123 \%$ (at $2 \mathrm{mM} \mathrm{Mg}^{2+}$ ) and $127 \%$ (at $10 \mathrm{mM} \mathrm{Mg}^{2+}$ ), respectively. Beluhan et al. (2003) studied the effects of different concentrations of $\mathrm{Mg}^{2+}$ on 5'-PDE from barley malt sprouts and found that the relative activity increased as the concentration of $\mathrm{Mg}^{2+}$ increased. 5'-PDE appeared to be more sensitive to $\mathrm{Ca}^{2+}$ activation compared to the other cations tested, where a significant activation could be seen at $2 \mathrm{mM} \mathrm{Ca}{ }^{2+}$. The highest relative activity was $296.0 \%$ at $4 \mathrm{mM} \mathrm{Ca}^{2+}$. After that, the activity of 5'-PDE remained relatively stable.

From Table 2, the relative activity of 5'-PDE increased, with an increase in $\mathrm{Ca}^{2+}$ concentration. Harvey et al. (1967) reported a high relative activity of
Table 2. Effects of metal cation concentration on the activity of 5'-phosphodiesterase

\begin{tabular}{|c|c|c|}
\hline $\begin{array}{l}\text { Metal } \\
\text { cations }\end{array}$ & Concentration, $\mathrm{mM}$ & $\begin{array}{c}\text { Relative enzyme } \\
\text { activity, } \%\end{array}$ \\
\hline \multirow[t]{6}{*}{$\mathrm{Li}^{+}$} & 0 & $100.0 \pm 0.0^{\mathrm{a}}$ \\
\hline & 2 & $95.5 \pm 6.6^{\mathrm{a}}$ \\
\hline & 4 & $102.6 \pm 15.7^{\mathrm{ac}}$ \\
\hline & 6 & $148.4 \pm 8.4^{b}$ \\
\hline & 8 & $132.8 \pm 5.2^{\mathrm{bc}}$ \\
\hline & 10 & $121.4 \pm 8.2^{\mathrm{c}}$ \\
\hline \multirow[t]{6}{*}{$\mathrm{Na}^{+}$} & 0 & $100.0 \pm 0.0^{\mathrm{a}}$ \\
\hline & 2 & $111.1 \pm 7.1^{\mathrm{a}}$ \\
\hline & 4 & $179.4 \pm 14.4^{\mathrm{b}}$ \\
\hline & 6 & $203.6 \pm 6.4^{\mathrm{c}}$ \\
\hline & 8 & $146.6 \pm 12.9^{c}$ \\
\hline & 10 & $77.8 \pm 8.1^{\mathrm{e}}$ \\
\hline \multirow[t]{6}{*}{$\mathrm{K}^{+}$} & 0 & $100.0 \pm 0.0^{\mathrm{a}}$ \\
\hline & 2 & $104.4 \pm 1.2^{\mathrm{a}}$ \\
\hline & 4 & $134.8 \pm 6.7^{\mathrm{b}}$ \\
\hline & 6 & $169.6 \pm 6.3^{\mathrm{c}}$ \\
\hline & 8 & $188.8 \pm 8.4^{\mathrm{d}}$ \\
\hline & 10 & $215.4 \pm 4.6^{\mathrm{e}}$ \\
\hline \multirow[t]{6}{*}{$\mathrm{Mg}^{2+}$} & 0 & $100.0 \pm 0.0^{\mathrm{a}}$ \\
\hline & 2 & $142.3 \pm 7.6^{\mathrm{b}}$ \\
\hline & 4 & $191.4 \pm 27.6^{c}$ \\
\hline & 6 & $231.5 \pm 15.3^{\mathrm{d}}$ \\
\hline & 8 & $207.4 \pm 6.7^{\mathrm{cd}}$ \\
\hline & 10 & $193.9 \pm 16.2^{\mathrm{c}}$ \\
\hline \multirow[t]{6}{*}{$\mathrm{Ca}^{2+}$} & 0 & $100.0 \pm 0.0^{\mathrm{a}}$ \\
\hline & 2 & $261.0 \pm 10.8^{\mathrm{b}}$ \\
\hline & 4 & $296.0 \pm 6.2^{\mathrm{c}}$ \\
\hline & 6 & $289.0 \pm 1.9^{c}$ \\
\hline & 8 & $274.0 \pm 6.3^{b}$ \\
\hline & 10 & $268.9 \pm 9.3^{\mathrm{b}}$ \\
\hline \multirow[t]{6}{*}{$\mathrm{Al}^{3+}$} & 0 & $100.0 \pm 0.0^{\mathrm{a}}$ \\
\hline & 2 & $71.2 \pm 1.8^{\mathrm{b}}$ \\
\hline & 4 & $66.7 \pm 2.9^{\mathrm{bc}}$ \\
\hline & 6 & $56.3 \pm 3.7^{c}$ \\
\hline & 8 & $50.6 \pm 0.6^{c}$ \\
\hline & 10 & $25.9 \pm 5.2^{\mathrm{d}}$ \\
\hline
\end{tabular}

Mean residual activity \pm standard deviation, $\%$. Residual activity, which has a different alphabet, indicates significant differences $(P<0.001)$ between concentrations, \%. 
$218 \%$ among the other metal cations when $2 \mathrm{mM} \mathrm{Ca}^{2+}$ is added to the 5'-PDE from carrots. Henz et al. (2007) reported that $0.5 \mathrm{mM}$ and $1 \mathrm{mM}$ of $\mathrm{Ca}^{2+}$ had no significant effect on 5'-PDE, which had been inhibited by EDTA from a rat mammary gland.

5'-PDE activity was negatively affected by the presence of $\mathrm{Al}^{3+}$ in the reaction mixture. As the concentration of $\mathrm{Al}^{3+}$ increased, the relative activity of enzyme activity decreased as well. At $10 \mathrm{mM}$ concentration, the relative activity of the enzyme was only $25.9 \%$ of the untreated enzyme. Ying et al. (2006) also reported that the enzyme activity decreased from $65 \%$ when $1 \mathrm{mM} \mathrm{Al}^{3+}$ was added to the reaction mixture to $54 \%$ when $2 \mathrm{mM}$ was incorporated. The results strongly suggest that 5'-PDE from adzuki beans is a metalloenzyme that is also sensitive to the presence of cations, causing the activity to either increase or decrease compared to the control without the addition of cations.

\section{CONCLUSIONS}

This study has shown that crude 5'-phosphodiesterase with a high-temperature optimum $\left(80^{\circ} \mathrm{C}\right)$ and alkaline $\mathrm{pH}$ optimum ( $\mathrm{pH} 8.5$ ) has been extracted from germinated adzuki beans. The enzyme is relatively stable between $\mathrm{pH} 7.0$ and 8.5. Higher stability was observed at $\mathrm{pH} 7.5$ compared to $\mathrm{pH} 8.5$, and at $60^{\circ} \mathrm{C}$ and $65^{\circ} \mathrm{C}$ the enzyme activity still possesses good efficiency even after 4 days of incubation. Increasing the temperature to more than $70^{\circ} \mathrm{C}$ affected the stability of the enzyme. This study has also shown that the activity of 5'-PDE extracted from germinated adzuki beans is affected by exogenously added metal ions in different ways. 5 '-PDE was slightly inhibited by detergents such as Tween 80 and Tween 20, while Triton X 100, SDS and EDTA were strong inhibitors. Cations such as $\mathrm{Ca}^{2+}$, $\mathrm{K}^{+}, \mathrm{Mg}^{2+}$ and $\mathrm{Li}^{2+}$ were found to enhance enzyme activities. The results further showed that the activity of the enzyme was at its highest in the presence of $\mathrm{Ca}^{2+}$, followed by $\mathrm{K}^{+}$and $\mathrm{Mg}^{2+}$, while $\mathrm{Li}^{+}$and $\mathrm{Na}^{+}$showed a slight increase up to a certain concentration only. When selected metal ions at different concentrations were tested against the enzyme, $\mathrm{Mg}^{2+}, \mathrm{Li}^{+}$and $\mathrm{Na}^{+}$ showed a similar pattern of enzyme activation, whereby increasing of metal ion concentration increased 5'-PDE activity until it reached its maximum activity at $6 \mathrm{mM}$. In all cases, the activity of the enzyme remained greater than the control. In the case of $\mathrm{Ca}^{2+}$, increasing the concentration beyond $4 \mathrm{mM}$ resulted in inhibition of activity. 5'-PDE activity increased as $\mathrm{K}^{+}$ concentration increased. On the other hand, 5'-PDE activity decreased as $\mathrm{Al}^{3+}$ concentration decreased. In conclusion, the metal cations that inhibited the activity of 5'-PDE were $\mathrm{Co}^{+}, \mathrm{Cu}^{2+}, \mathrm{Zn}^{2+}, \mathrm{Hg}^{+}, \mathrm{Ba}^{2+}, \mathrm{Al}^{3+}, \mathrm{Pb}^{2+}$, $\mathrm{Ni}^{2+}$ and $\mathrm{Fe}^{3+}$ at $10 \mathrm{mM}$. Thus, it is concluded that 5'-PDE from adzuki beans is a metalloenzyme. As well as this, activation of the enzyme with the addition of $\mathrm{Na}^{+}(6 \mathrm{mM})$ suggests its possible incorporation into the extract to enhance enzyme catalysis.

\section{ACKNOWLEDGMENTS}

The author would like to express her deepest gratitude to Universiti Putra Malaysia for the Graduate Research Scholarship (GRF) in supporting her study.

\section{REFERENCES}

Aoyagi, H., Akimoto-Tomiyama, C., Tanaka, H. (2006). Preparation of mixed alginate elicitors with high activity for the efficient production of 5-phosphodiesterase by Catharanthus roseus cells. Biotechnol. Lett., 28, 1567-1571. https://doi.org/10.1007/s10529-006-9124-5

Beluhan, S., Karmelic, I., Novak, S., Maric, V. (2003). Partial purification and biochemical characterization of alkaline 5'-phosphodiesterase from barley malt sprouts. Biotechnol. Lett., 25, 1099-1103. https://doi.org/10.1023/ A:1024144215414

Beluhan, S., Maric, V. (2011). Comparative biochemical characterization of 5'-phosphodiesterase and phosphomonoesterase from barley malt sprouts. Nat. Prod. Commun., 6, 73-78. https://doi.org/10.1177/1934578X1100 600118

Bowles, L. K. (1991). 5'-phosphodiesterase enzyme preparation and methods for its production. US Pat., 5034325.

Chohnan, S., Nagata, T., Midorikawa, Y. (1994). Purification and characterization of a novel bifunctional enzyme, cyclic-ribonucleotide phosphomutase-5'-phosphodiesterase, from Aspergillus niger. Biosci. Biotech. Bioch., 58, 250-255. https://doi.org/10.1271/bbb.58.250

Dhule, S. S., Shetty, P. R., Iyer, J., Singhal, R. S. (2006). Purification and characterization of 5'-phosphodiesterase from germinated barley. Process Biochem., 41, 18991902. https://doi.org/10.1016/j.procbio.2006.03.041 
Pui, L. P., Mohammed, A. S., Ghazali, H. M. (2020). Characterization of crude 5'-phosphodiesterase from germinated adzuki (Vigna angularis L.) beans. Acta Sci. Pol. Technol. Aliment., 19(3), 319-331. http://dx.doi.org/10.17306/J.AFS.2020.0804

Flaganan, P. R., Zbarsky, S. H. (1976). Purification of phosphodiesterase II from rat and guinea-pig intestinal mucosa. Biochem. J., 155, 607-613. https://doi.org/10.1042/ bj1550607

Futai, M., Mizuno, D. (1967). A new phosphodiesterase forming nucleotide 5'-monophosphate from rat liver. J. Biol. Chem., 242, 5301-5307.

Harvey, C., Malsman, L., Nussbaum, A. L. (1967). A phosphodiesterase from carrot. Biochemistry, 6, 3689-3694. https://doi.org/10.1021/bi00864a011

Harvey, C., Olson, K. C., Wright, R. (1970). Further purification and properties of phosphodiesterase from the carrot. Biochemistry, 4, 921-925. https://doi.org/10.1021/ bi00806a030

Henz, S. L., Furstenau, C. R., Chiarelli, R. A., Sarkis, J. J. F. (2007). Kinetic and biochemical characterization of an ecto-nucleotide pyrophosphate/phosphodiesterase (EC 3.1.4.1) in cells cultured from submandibular salivary glands of rats. Arch. Oral Biol., 1906, 1-8. https://doi. org/10.1016/j.archoralbio.2007.03.006

Hua, J., Huang, K. L. (2010). Preparation and characterization of 5'-phosphodiesterase from barley malt rootlets. Nat. Prod. Commun., 5, 265-268. https://doi. org/10.1177/1934578X1000500220

Idris, Y. M. A. (2000). Kesinai (Streblus asper) protease as a potential milk coagulation enzyme. PhD Thesis. University Putra Malaysia.

Jones, A. M. (2003). Practical skills in biology (3rd ed.). Harlow: Prentice Hall.

Khutle, N. M., Vijaya, D. C., Pawar, H., Jodhe, P., Gaikar, A. (2011). Extraction, partial purification and characterization of 5'-phosphodiesterase from germinated Phaseolus mungo (mung bean). Int. J. Pharm. Phytopharm. Res., 1, 55-56.

Lassila, J. K., Herschlag, D. (2008). Promiscuous sulfatase activity and thio-effects in a phosphodiesterase of the alkaline phosphatase superfamily. Biochemistry, 47, 12853-12859. https://doi.org/10.1021/bi801488c

Lerch, B., Wolf, G. (1972). Isolation of phosphodiesterase from sugar beet leaves. Biochim. Biophys. Acta, 258, 206-218. https://doi.org/10.1016/0005-2744(72)90979-5

Luo, Z., Fan, Y., Li, Q., Han, B., Liu, Y., Li, S., ..., Pang, Z. (2017). Isolation, purification and characterization of 5'-phosphodiesterase from Aspergillus fumigatus. PloS One, 12(10), e0186011. https://doi.org/10.1371/journal. pone. 0186011

Maldonado, P. A., de Carvalho Corrêa, M., Becker, L. V., Flores, C., Moretto, M. B., Morsch, V., Schetinger, M. R. C. (2008). Ectonucleotide pyrophosphatase/phosphodiesterase (E-NPP) and adenosine deaminase (ADA) activities in patients with uterine cervix neoplasia. Clin. Biochem., 41(6), 400-406. https://doi.org/10.1016/j. clinbiochem.2007.12.019

Miller, D. J., Shuvalova, L., Evdokimova, E., Savchenko, A., Yakunin, A. F., Anderson, W. F. (2007). Structural and biochemical characterization of a novel $\mathrm{Mn}^{2+}$-dependent phosphodiesterase encoded by the $y f c E$ gene. Protein Sci., 16, 1338-1348. https://doi.org/10.1110/ ps.072764907

Olczak, M., Kobialka, M., Watorek, W. (2000). Characterization of diphosphonucleotide phosphatase/phosphodiesterase from yellow lupin (Lupinus luteus) seeds. Biochim. Biophys. Acta, 1478, 239-247. https://doi. org/10.1016/S0167-4838(00)00024-8

Pelczar, M. J., Chan, E. C. S., Kring, N. R. (2004). Microbiology (5th ed.). New Delhi: Tata McGraw-Hill.

Pui, L. P., Abdulkarim, S. M., Ghazali, H. M. (2012). Effects of germination conditions on 5'-phosphodiesterase activity of selected seeds. Int. Food Res. J., 19(4), 1641-1648.

Rosemeyer, H., Ramzaeva, N., Becker, E. M., Feiling, E., Seela, F. (2002). Oligonucleotides incorporating 7-(aminoalkyl)-7-deaza-2'-deoxyguanosines: duplex stability and phosphodiester hydrolysis by exonucleases. Bioconjugate Chem., 13, 1274-1285. https://doi.org/ 10.1021/bc020024q

Rotola-Pukkila, M., Yang, B., Hopia, A. (2019). The effect of cooking on umami compounds in wild and cultivated mushrooms. Food Chem., 278, 56-66. https://doi. org/10.1016/j.foodchem.2018.11.044

Santoro, N., Cirillo, G., Lepore, M. G., Palma, A., Amato, A., Savarese, P., ..., del Giudice, E. M. (2009). Effect of the rs 997509 polymorphism on the association between ectonucleotide pyrophosphatase phosphodiesterase 1 and metabolic syndrome and impaired glucose tolerance in childhood obesity. J. Clin. Endocrinol. Metab., 94, 300-305. https://doi.org/10.1210/jc.2008-1659

Scopes, R. K. (2013). Protein purification: principles and practice. Springer Science \& Business Media.

Singh, S. K., Singh, S. S., Pandey, V. D., Mishra, A. K. (2006). Factors modulating alkaline phosphatase activity in the diazotrophic rice-field cyanobacterium, Anabaena oryzae. World J. Microb. Biot., 22, 927-935. https:// doi.org/10.1007/s11274-006-9137-1

Sombutyanuchit, P., Suphantharika, M., Verduyn, C. (2001). Preparation of 5'-GMP-rich yeast extracts from spent brewer's yeast. World J. Microb. Biot., 17(2), 163-168.

Sowdhamini, R., Balaam, P. (1993). Protein structure and stability. In M. N. Gupta (Ed.), Thermostability of enzymes. Delhi: Narosa Publishing House. 
Speath, B., Settele, F., Schilling, O., Dangelo, I., Vogel, A., Feldmann, I., ..., Marchfelder, A. (2007). Metal requirements and phosphodiesterase activity of tRNAase Z enzymes. Biochemistry, 46, 14742-14750. https://doi. org/10.1021/bi7010459

Takahama, Y., Uto, H., Kanmura, S., Oketani, M., Ido, A., Kusumoto, K., ..., Tsubouchi, H. (2008). Association of a genetic polymorphism in ectonucleotide pyrophosphatase/phosphodiesterase 1 with hepatitis $\mathrm{C}$ virus infection and hepatitis $\mathrm{C}$ virus core antigen levels in subjects in a hyperendemic area of Japan. J. Gastroenterol., 43, 942-950. https://doi.org/10.1007/s00535-008-2256-8

Takebayashi, S., Ikeda, M., Takeuchi, M., Shinkai, S. (2004). Metal ion induced allosteric transition in the catalytic activity of an artificial phosphodiesterase. Org. Biomol. Chem., 6, 493-499.
Utami, T., Maharani, S., Nur Chahyanto, M. (2011). Activity of 5'-phosphodiesterase isolated from various germinated beans. The 12th ASEAN Food Conference, Bangkok, Thailand.

Wang, A. Y., Juang, R. H., Chang, C. T., Sung, H. Y. (1993). Purification and characterization of 5'-phosphodiesterase from barley rootlets. Biochem. Mol. Biol. Int., 6, 1095-1102.

Ying, G. Q., Shi, L. E., Yu, Y., Tang, Z. X., Chen, J. S. (2006). Production, purification and characterization of nuclease $\mathrm{p} 1$ from Penicillium citrinum. Process Biochem., 41, 12761281. https://doi.org/10.1016/j.procbio.2005.12.028

Zou, H. C., Cai, G. Y., Cai, W., Li, H. L., Gu, Y., Park, Y. D., Meng, F. G. (2008). Extraction and DNA digestion of 5'-phosphodiesterase from malt root. Tsinghua Sci. Technol., 13, 480-484. 